Article

\title{
Comparative Patterns of Migration Intentions: Evidence from Eastern European Students in Economics from Romania and Republic of Moldova
}

\author{
Aurelian-Petruș Plopeanu ${ }^{1}\left(\right.$, Daniel Homocianu ${ }^{2, *}$, Nelu Florea ${ }^{3}$, Ovidiu-Aurel Ghiuță 4 \\ and Dinu Airinei ${ }^{5}$ \\ 1 Department of Social Sciences and Humanities, Institute of Interdisciplinary Research, Alexandru Ioan Cuza \\ University of Iași, Alexandru Lăpușneanu Street, No.14, 700057 Iași, Romania \\ 2 Department of Accounting, Business Information Systems and Statistics, Faculty of Economics and Business \\ Administration, Alexandru Ioan Cuza University of Iași, Carol I, Blvd., No. 22, Building B, room B330A, \\ 700505 Iași, Romania \\ 3 Department of Management, Marketing and Business Administration, Faculty of Economics and Business \\ Administration, Alexandru Ioan Cuza University of Iași, 700505 Iași, Romania \\ 4 Department of Food Technology, Food Production and Environmental Safety, Stefan cel Mare University of \\ Suceava, 720204 Suceava, Romania \\ 5 Department of Accounting, Business Information Systems and Statistics, Faculty of Economics and Business \\ Administration, Alexandru Ioan Cuza University of Iași, Carol I, Blvd., No. 22, Building B, Room B308, \\ 700505 Iași, Romania \\ * Correspondence: dan.homocianu@gmail.com; Tel.: +40-232-20-1413
}

Received: 6 June 2019; Accepted: 5 September 2019; Published: 10 September 2019

Abstract: Based on a survey among students in economics at universities from the Romanian region of Moldova (RoMold) and Republic of Moldova (ReMold), this study explores the influence of familial, background, and individual characteristics on the migration intentions abroad. Both regional models built after using data mining tools and binary logistic regression analysis show a powerful emphasis on our own value recognition, while the other influences indicate clear asymmetric patterns in terms of migration intentions. For RoMold, there is a low level of interpersonal trust, a strong accent on individual liberty and favoritism, a low respect for traditions, and the belief that Orthodoxy could be a migration cause. The paternal occupation and the maternal religiosity matter for their migration plans. For ReMold, the parental migration experience, a low level of parents' education attainment, and a powerful internal locus of control are considered the main triggers for migrating abroad. For both particular regions, a highly interactive distribution map and two corresponding risk-prediction nomograms provide basic support for replication, fast visual insight, and consistent support for interpretations directly in probabilistic terms. We intend to apply an inductive approach in order to extend the analysis to different types of respondents and geographic areas.

Keywords: migration intentions; own value recognition; familial and individual features; interactive distribution map; data mining; binary logistic regression; risk-prediction nomograms

\section{Introduction}

In today's highly globalized human communities and knowledge-based economies, the dynamics of migration is a fact that encompasses complex facets and generates divergent spillovers for both sending and receiving countries. Often, it is considered that the "brain drain" processes have negative consequences on the countries of origin because they affect primarily strategic sectors, such as health and education. Therefore, even if local conditions are difficult, some countries struggle to keep their highly-skilled individuals home or even have them return to their country of origin [1]. 
By contrast, the positive effects of such decisions on sending countries could be related with increased remittances, foreign direct investment or trade [2], inputs that may stimulate consumption, local investment, and educational attainment [3].

The migration phenomenon is interesting to study because, after the fall of communism and then the integration in the European Union and NATO (in the case of Romania), the outflows of migrants abroad increased [4]. While the majority of Romanian and Moldavian migrants prefer mobility to Western European countries, the political and economic turmoil that recently affected them influenced and exerted a powerful influence on present and future decisions to migrate. The factors taken into consideration include the global crisis from 2008, the crisis of refugees from 2014, and Brexit or the withdrawal of the United Kingdom from the European Union [5].

It is outlined that more than half of migrants around the world are coming from developed countries [6]. Migration has become an issue for both Romania and the Republic of Moldova. The Republic of Moldova has one of the highest levels of migration, around 25\% of its population migrates abroad temporarily or permanently. Out of this percent, a large proportion is represented by young individuals [7]. The same is valid for the Romanian region of Moldova [8].

The focus on the students' intentions to migrate is due to higher adaptability to host societies, ease of interacting with locals [9], and the fact that they are considered one of the most attractive categories of migrants [10].

There are few studies that examine migration patterns and intentions in cities and villages of Romania and the Republic of Moldova, with the accent being put mostly on nurses and doctors' intentions to migrate. Even fewer have analyzed the potential mobility of students in economics from both Romania and the Republic of Moldova. Our exploratory study adds to the literature of the field, which includes a cross-country analysis of the migration potential from different angles. First of all, we focus on students in economics, who are usually very tempted to migrate. Second, we take into consideration both the Romanian-language speaking communities on both sides of the Prut River (RoMold, which includes 8 counties: Suceava, Botoșani, Iași, Neamt, Bacău, Vaslui, Vrancea and Galați, and ReMold). Other arguments for choosing these two areas are due to: their neighborhood, their common history, culture, and ethnicity, and the real phenomenon that numerous students from the Republic of Moldova come to study in Romanian universities (especially in Iași and Suceava). After they receive Romanian citizenship, they prefer to migrate further to Western Europe [7]. Third, we are expanding migration research by taking into account the role of personal motivations and aspirations, especially the concept of personal value recognition through migration abroad.

While values and circumstances in the case of these young adults may change over time, it is important to analyze the migration intentions among them because they could be potential immigrants over time [11]. Our aim was to analyze the migration intentions among the students in economics from two Romanian universities (Iași and Suceava) and two Moldavian ones (Chișinău and Bălți). Further on, we were interested in exploring the main drivers for these potential behaviors, the common influences, and the different ones. The main triggers are mainly related to familial and background (parental education attainment, career, religiosity, migration experience, family size, living in urban areas, income level etc.), and individual reasons (age, gender, trust in other people and in institutions, inherited values, and ethical values). The findings indicate that internal and external components influence, to a certain degree, the plans to migrate abroad in the future for both Romanian and Moldavian young adults. These influences underline different aspects, which may be important to consider by the Romanian and Moldavian policymakers, especially those issues of the efficient and transparent functioning of public institutions.

The paper is structured as follows. The next section briefly reviews the relevant literature regarding this phenomenon and the particular findings related to the migration intentions abroad among young adults. Section 3 provides details about the data collected through a questionnaire-based survey and the methods used for analyzing them. Section 4 presents the main results after conducting empirical 
analyses and the interpretations based on these findings. In the last section, we discuss the conclusions of this research.

\section{Literature Review}

In this paper, we analyze the likelihood of the intention to migrate versus to stay in the country of origin, considering that these two are highly connected with several background, individual, and socio-professional aspects [12-15]. Migration represents, for the young adults, a period needed for maturity [16]. The intentions are a determinant factor for real decision-making [17-20], which is a necessary and valuable variable [21], with even the most prominent predictor of migration experience [22,23]. Other studies demonstrated that, when an individual had a mental expectation to move, then a real decision for mobility was made [24]. The positive role played by these intentions for a real mobility plan is emphasized [21] (p. 14), even if they will not be put in practice [25]. Therefore, the migration potential is a variable very often used in the migration research [26]. While most of the research was based exclusively on micro-level data, other research studied international migration and confirmed that migration intentions are predictors of actual decisions [27].

In the context of insufficient or even no data regarding migration flows outside the country of origin, the data obtained through surveys on emigration intentions as proxies are extremely important for national decision makers [28]. It was emphasized that the perceptions regarding the levels of emigration intentions could indicate that, in the future, the migration phenomenon could show an increase [27]. In terms of intentions, a study conducted by the Romanian Institute for Evaluation and Strategy (IRES 2013) among 1221 respondents aged 18 years old and older, found that $64 \%$ of those aged between 18 and 35 years old were (very) interested in working abroad, while the highest intentions were recorded in the region of Moldova (42\%) [29]. This is why it is important to understand migration future plans and its influencing factors, in order to anticipate future mobility flows abroad [28].

In a study conducted in nine European countries among young people and using YMOBILITY data, interesting facts are presented. The Romanians recorded the highest percentage willing to migrate in the next five years (48\%), with the most important reasons being connected with low perspectives regarding jobs and incomes, especially salaries $(89 \%)$, employment prospects $(88 \%)$, general welfare $(85 \%)$, acquiring new job skills $(84 \%)$, and career advancement opportunity (82\%) [30]. All these variables are connected with our models' core, which is our own value recognition.

In our study, we analyze only the firm migration intentions among the Romanian and Moldavian students in economics. Therefore, we have excluded from the very beginning, the ambivalent option "I do not know" as a possible answer for the question asking about migration intentions. The decision to analyze the intention of students in economics to migrate abroad is motivated by other previous empirical findings. The importance of the courses of study has an influence on future migration perspectives. It was empirically found that the students in economics and business administration and also the graduates are much more predisposed to leave their country of origin in comparison with other students from different faculties [31-33].

The analysis of migration intentions worldwide received some attention in recent years. The most clear reasons that may affect the decision to migrate abroad are those related to money, for better standards of living, and for professional reasons [34,35], especially in the case of low-income countries' migrants who would opt to move into high-income ones [36] or from rural to urban regions [37]. In the case of migrants from transition economies, it was demonstrated that this phenomenon brought a better perception of well-being [38].

It was found that the individuals willing to migrate in the future are mostly underemployed ones, according to data from Gallup for the period 2009-2013 [39]. It is considered that migration intentions may become a real decision when considering highly skilled individuals and when the opportunities abroad flourish, while, for low skilled individuals, the level of income is the most important trigger [40]. Other scholars demonstrate that higher migration intentions are observed for relatively young and educated individuals [41]. It was found that the likelihood to migrate abroad is lower when the 
individuals are satisfied with the services provided by public institutions [42], while others underlined the negative influence exerted by government expenditure on social protection (as percentage in GDP) on the migration intentions [43]. The authors explained this relationship through each individual's subjective perceptions that such a welfare state gives them safety that would, otherwise, have led them to leave their country of origin for better standards of living.

While the reasons behind the wish to move abroad are especially determined by factors related to income and job opportunities, the existing networks [44,45], especially family ones [46], could be a potential stimulating predictor. In addition, closer ties with family members in the country of origin could decrease the migration intentions due to financial and psychological motives [47]. For example, it was demonstrated that the choice to migrate is not solely an individual decision, but is determined by the expectations of other family members [48]. In the case of Eastern European students, it was stressed that the lower the family centrality, the higher the propensity to migrate abroad [49].

Several studies explained that parental religiosity has an important influence on the children's social capital [50] and personal religiosity [51]. Hence, these children could be more attached to their local networks, and become less predisposed to migrate.

Wiese and Freund [52] found that these role models matter when parental actions are compatible with the children's childhood desires. Choosing parents' level of education and occupation are also important inputs for our analysis because they argue the influence of the parental role models. For example, higher educated parents represent an opportunity for their children to obtain the same education [53], which increases their migration potential [54]. It is considered that parental occupations positively or negatively influence the children's migration intentions $[55,56]$.

Some researchers consider that the subjective well-being is a variable that better captures the "silent" migration predictors than the income, stressing that the individuals who have higher subjective well-being levels are less likely to prefer to migrate abroad [57]. More non-economic reasons other than economic rationales may influence this potential decision to migrate abroad, which are almost invisible triggers for many research studies [58,59]. In the case of second-generation Turkish individuals who live in European countries, several scholars emphasized that migration intentions to Turkey are mostly influenced by an increase of religiosity and perceived discrimination [60].

The role of personality traits in the will to move abroad is highly important because they may draw particular attitudes and behaviors [60], which are elements incorporated into the subjective decision-making process [61] that generate different constraints [62]. The locus of control may play a role in migration decisions [63]. It was stressed that highly self-efficacious individuals present the highest migration intentions and actual migration behavior [64]. Moreover, it was demonstrated that highly educated individuals adapt more easily than the lower educated ones in different cultural environments [65]. Other migration potential determinants are gender [66], life satisfaction [67], or previous migration experience [68].

Moreover, we have previously conducted two research studies focused on migration intentions among Romanian students. The first one analyzes the migration enablers of students in theology [69] based on 400 distinct responses from two universities from Iasi and Sibiu. The corresponding results confirmed that the personal value recognition is also their main trigger for migration intentions. In addition, we found several influences related to personality traits, interpersonal trust, and preferred occupations. The second one [70] was based on 3051 distinct responses of students in economics from universities of Iasi, Cluj-Napoca, and Sibiu, at that time corresponding to three distinct regional models. The latter two are cities from Transylvania, which is a Romanian territory once under the former occupation of the long-gone Habsburg Empire and closer to the Western European countries. The results also emphasized the strong influence of the variable associated with personal value recognition on students' migration intentions. Other significant predictors are given by parental role models, favoritism, individual freedom, and religiosity. All these results encouraged us to make further investigations on the eastern part of Romania and the Republic of Moldova (former Romanian territory). 
Consequently, we included items related to all those findings above in the questionnaire design (Table 1), namely: (1) background and family features such as values inherited from parents together with their educational attainment, occupational profile, level of religiosity, migration experience, family size, and urban residence, (2) individual characteristics such as: gender, age, and attitudes regarding interpersonal trust, possible causes of migration, and ethical and social values.

Table 1. Variables and corresponding questions used for this study.

\begin{tabular}{|c|c|c|}
\hline Variables & Item in the Questionnaire & Variable Coding \\
\hline \multicolumn{3}{|c|}{ Family/Background Characteristics } \\
\hline inh_val_last_consci_work & $\begin{array}{l}\text { Do you consider that you have received from } \\
\text { your parents the quality of lasting and } \\
\text { conscientious work? }\end{array}$ & 1 -yes, 0 -no \\
\hline inh_val_indep & $\begin{array}{l}\text { Do you consider that you have received from } \\
\text { your parents the quality of being independent } \\
\text { (autonomous)? }\end{array}$ & 1 -yes, 0 -no \\
\hline inh_val_sense_of_resp & $\begin{array}{l}\text { Do you consider that you have received from } \\
\text { your parents the quality associated with a } \\
\text { sense of responsibility? }\end{array}$ & $1-$ yes, 0 -no \\
\hline inh_val_persev & $\begin{array}{l}\text { Do you consider that you have received from } \\
\text { your parents the quality of perseverance } \\
\text { (ambition)? }\end{array}$ & 1 -yes, 0 -no \\
\hline inh_val_resp4tradit & $\begin{array}{l}\text { Do you consider that you have received from } \\
\text { your parents the quality associated with } \\
\text { respect for traditions/past? }\end{array}$ & 1 -yes, $0-$ no \\
\hline m_edu & $\begin{array}{l}\text { What is your mother's highest level of } \\
\text { education completed? }\end{array}$ & years of total schooling \\
\hline d_edu & $\begin{array}{l}\text { What is your father's highest level of } \\
\text { education completed? }\end{array}$ & years of total schooling \\
\hline no_of_sibl & How many brothers (sisters) do you have? & $\begin{array}{l}\text { 10-point Likert scale, from } \\
0 \text { to } 9, \text { where } 9 \text { indicates } \\
\text { more than } 8 \text { siblings }\end{array}$ \\
\hline income_lvl & $\begin{array}{l}\text { What is your household monthly income } \\
\text { level? ( } 1 \text { for }<1500,2 \text { for } 1500-2499 \ldots 7 \text { for } \\
\text { more than } 6500 \text { RON) }\end{array}$ & 7-point Likert scale \\
\hline both_p_priv & $\begin{array}{l}\text { Have both of your parents worked or are } \\
\text { currently working in the private sector? }\end{array}$ & $1-$ yes, $0-$ no \\
\hline only_mom_priv & $\begin{array}{l}\text { Has only your mother worked or is currently } \\
\text { working in the private sector? }\end{array}$ & 1 -yes, 0 -no \\
\hline only_dad_priv & $\begin{array}{l}\text { Has only your father worked or is currently } \\
\text { working in the private sector? }\end{array}$ & 1 -yes, 0 -no \\
\hline both_p_faith_God & Do both your parents believe in God? & 1 -yes, 0 -no \\
\hline only_mom_faith_God & Does only your mother believe in God? & 1 -yes, 0 -no \\
\hline only_dad_faith_God & Does only your father believe in God? & 1 -yes, 0 -no \\
\hline both_p_gone_abroad & $\begin{array}{l}\text { Have both of your parents been abroad for } \\
\text { more than a year? }\end{array}$ & 1 -yes, 0 -no \\
\hline only_mom_gone_abroad & $\begin{array}{l}\text { Has only your mother been abroad for more } \\
\text { than a year? }\end{array}$ & 1 -yes, 0 -no \\
\hline only_dad_gone_abroad & $\begin{array}{l}\text { Has only your father been abroad for more } \\
\text { than a year? }\end{array}$ & 1 -yes, 0 -no \\
\hline urban & $\begin{array}{l}\text { Did you live in an urban residential } \\
\text { environment? }\end{array}$ & 1 -yes, 0 -no \\
\hline
\end{tabular}


Table 1. Cont.

\begin{tabular}{|c|c|c|}
\hline Variables & Item in the Questionnaire & Variable Coding \\
\hline \multicolumn{3}{|c|}{ Individual Characteristics } \\
\hline male & What is your gender? & $\begin{array}{l}1 \text {-male } \\
0 \text {-female }\end{array}$ \\
\hline age & How old are you? & Years \\
\hline interpers_trust_lvl & $\begin{array}{l}\text { Generally speaking, would you consider that } \\
\text { most people can be trusted? }\end{array}$ & $\begin{array}{l}\text { 5-point Likert scale, from } \\
\text { 1-complete distrust to } \\
\text { 5-complete trust }\end{array}$ \\
\hline clear_intent_to_migr (OUTCOME) & $\begin{array}{l}\text { After graduation, do you want to migrate to } \\
\text { Western Europe (WE)? }\end{array}$ & 1 -yes; 0 -no \\
\hline clear_eq_migrWEur_pers_val_recog & $\begin{array}{l}\text { For you, is migrating to WE equivalent with } \\
\text { your own value recognition and, therefore, } \\
\text { equivalent with obtaining what you } \\
\text { want/deserve? }\end{array}$ & 1 -yes; 0 -no \\
\hline communist_past_migr_cause & $\begin{array}{l}\text { Do you consider the communist past that has } \\
\text { left deep traces in local mentalities and } \\
\text { institutions as a cause for many people to } \\
\text { migrate to WE? }\end{array}$ & 1 -yes; 0 -no \\
\hline orthodoxy_migr_cause & $\begin{array}{l}\text { Do you think that Orthodoxy is blocking free } \\
\text { initiative and is why many people migrate to } \\
\text { WE? }\end{array}$ & 1 -yes; 0 -no \\
\hline lower_wages_migr_cause & $\begin{array}{l}\text { Do you consider lower wages to be a cause } \\
\text { for many people to migrate to WE? }\end{array}$ & 1 -yes; 0 -no \\
\hline lower_prof_satisf_migr_cause & $\begin{array}{l}\text { Do you consider the lower satisfactions } \\
\text { generated by professional life as a cause for } \\
\text { many people migrating to WE? }\end{array}$ & 1 -yes; 0 -no \\
\hline excesive_bureaucracy_migr_cause & $\begin{array}{l}\text { Do you consider the excessive bureaucracy } \\
\text { that blocks any individual initiative as a cause } \\
\text { for many people to migrate to WE? }\end{array}$ & 1 -yes; 0 -no \\
\hline bad_luck_migr_cause & $\begin{array}{l}\text { Do you consider that bad luck is the cause for } \\
\text { many people to migrate to WE? }\end{array}$ & 1 -yes; 0 -no \\
\hline injust_in_soc_migr_cause & $\begin{array}{l}\text { Do you consider that injustice in our society is } \\
\text { the cause for many people to migrate to WE? }\end{array}$ & 1-yes; 0 -no \\
\hline accept_or_doubts_undsrv_st_fiAdv & $\begin{array}{l}\text { Would it be justifiable to receive undue } \\
\text { financial benefits from the state? }\end{array}$ & 1 -yes; 0 -no \\
\hline only_strong_conn4cl_acc_in & $\begin{array}{l}\text { Do you think that, in your own country, you } \\
\text { can evolve professionally only on the basis of } \\
\text { favoritism? }\end{array}$ & 1-yes; 0 -no \\
\hline indiv_lib_clear_cause_of_progr & Individual liberty is a factor of progress? & 1-yes; 0 -no. \\
\hline
\end{tabular}

Following all these previous ideas, we formulate and aim to validate a set of hypotheses related to the existing findings and have a direct correspondence with the questionnaire items we used.

Hypothesis 1. The students who put great emphasis on their own value recognition are more likely to intend to migrate.

Hypothesis 2. The family background in terms of parental education attainment, migration experience, occupation, religiosity, and inherited values from them exerts a strong influence on migration intentions.

Hypothesis 3. The students who manifest a high level of interpersonal trust and consider individual liberty as the main source of progress are more inclined to leave their country of origin. 
Hypothesis 4. The individuals who manifest a negative attitude toward a welfare state and favoritism are more likely to migrate abroad.

Hypothesis 5. Both subgroups present symmetric patterns in terms of migration intentions due to similarities in terms of history, culture, religion, language, and ethnicity.

\section{Data and Methods}

Due to the lack of statistical data regarding migration intentions among students, during the university year 2018-2019, we have collected data from the faculties of economics of four universities (Alexandru Ioan Cuza University of Iași-UAIC, Ștefan cel Mare University of Suceava-USV, Alecu Russo University of Bălți-UAR, and Academy of Economic Studies from Chișinău-ASEM, the first two from RoMold and the last two form ReMold). This data was collected through questionnaire-based surveys among the students in economics focused on migration intentions. The questions are related with a set of variables considered in relation to migration intentions, which are grouped on individual and family/background characteristics (see Table 1). The criterion for constructing the sample was based on randomly including students from both undergraduate and master programs of study coming from different locations with various standards of living. We ensured that all four samples contained a broad variety of programs (economics, international business, business administration, public administration, management, marketing, banking and finance, accounting, business information systems, trade, tourism and services, economic statistics, and forecasting). The ratio between the sample and the population size for each of all four faculties from corresponding university centers was about 20\% (1475/7000 for UAIC, 330/1900 for USV, 400/2200-UAR, and 550/3100 for ASEM) and the response rate overpassed the value of $95 \%$ in all four cases (1467/1475 for UAIC, 329/330 for USV, 387/400-UAR, and 524/550 for ASEM). We considered the students' permanent residencies and not the university centers where they study, as the criteria for splitting all 2707 responses into two subsets for both regions above (RoMold and ReMold).

We paid respect to the triangulation principle as the strategic use of multiple approaches to address one question and get similar results across different methodologies, which are less likely to generate a false image of the phenomenon investigated [71]. Consequently, in order to achieve solid results in our research, we have involved many approaches, methods, and instruments.

The data was cleaned using the OpenRefine tool. For additional derivations, we used spreadsheet built-in functions (text, logical, lookup and reference, etc.), powerful filters (e.g., text oriented with the "contains" option), and find-and-replace facilities.

The geographical distribution of responses was represented using the Google Fusion Tables online tool able to generate query-able and highly interactive maps with iconographic support (e.g., corresponding to the permanent residence of respondents as declared, according to the identity card and translated into pairs of coordinates). We considered many reasons to involve such representations, namely: (1) the principles of transparency and support for replication of results that are effectively suggested and supported through a map (Figure 1), which visually urges the reader to easily access the representation and get (in two steps/clicks: Direct link to its source and then "Rows 1" button) and use the entire data source behind it, (2) the principle of support for interactivity, which is better emphasized by including a figure with a map with two opposite states (by default, without filtering and customized, with various possible filters) designed to suggest the dynamics of the representation, (3) the fact that this type of representation better suggests the broad distribution of respondents' residence across the studied regions, and (4) the well-known guiding principle that 'a good picture paints a thousand words.' 


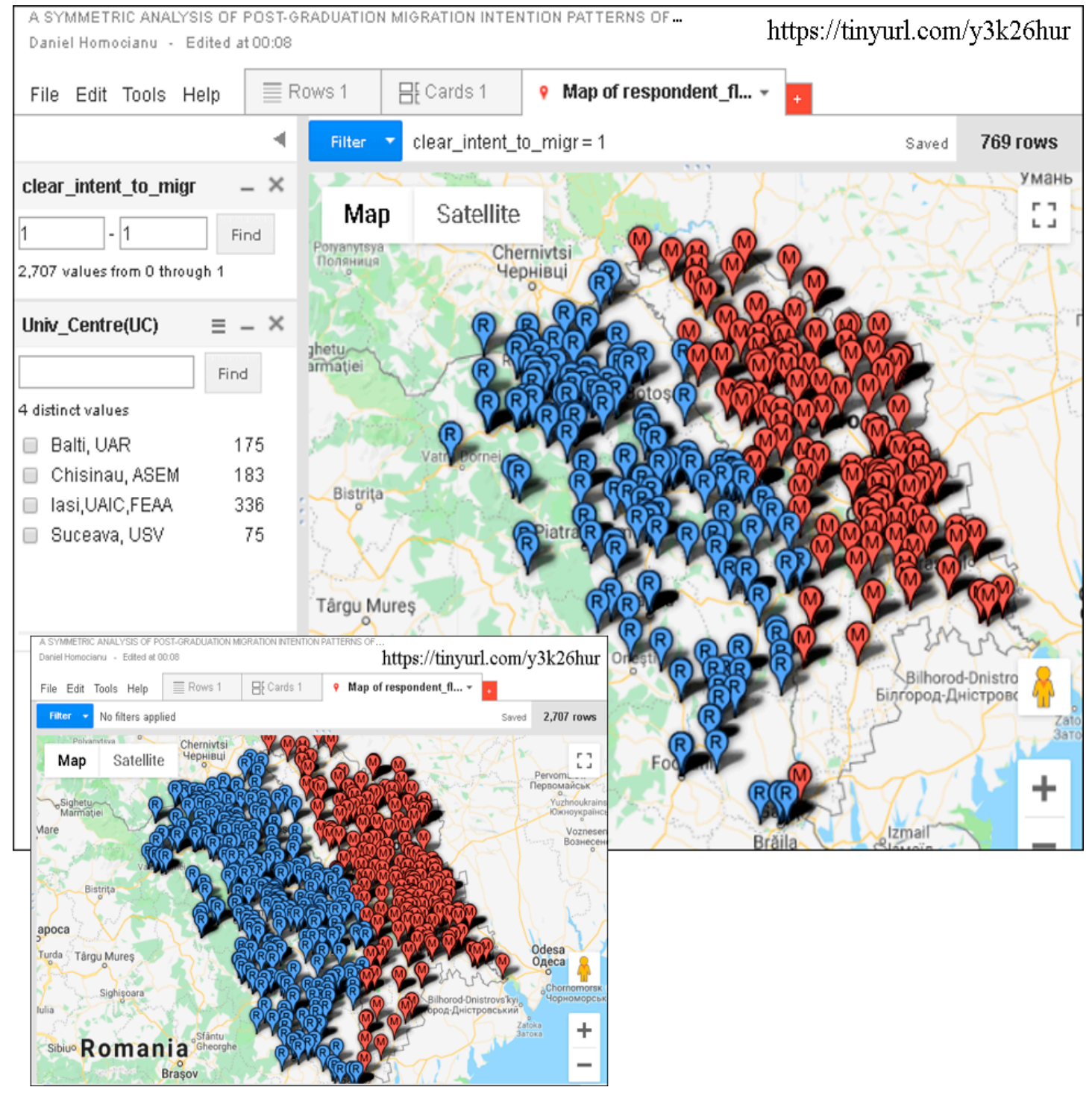

Figure 1. Online queryable map of responses' distribution ( $\mathrm{R}$ for RoMold, $\mathrm{M}$ for ReMold) considering a filter on the core variable and no filters, respectively [72].

In order to identify the common and most powerful influence/influences (models' core), we have used three classification algorithms based on Decision Trees, Naive Bayes, and Neural Networks considering the entire data set and the two subsets corresponding to RoMold and ReMold. All three are available after installing the Microsoft Data Mining (DM) add-in for Excel spreadsheets with persistence and support for queries (SQL DMX—the Data Mining eXtension of the well-known Structured Query Language) ensured by SQL Server Analysis Services (SSAS).

In order to estimate the students' migration intentions, assess the most important influences, and test the validity of all hypotheses above, we used a general econometric model based on binary logistic regressions (logit—Equation (1)) for both subsets.

$$
\operatorname{Logit}(\mathrm{p})=\ln \left(\frac{\mathrm{p}}{1-\mathrm{p}}\right)=\beta_{0}+\sum_{j=1}^{\mathrm{m}} \beta_{j} * X_{j}+\varepsilon,
$$

where: $\mathrm{p}$-is the probability of migration intentions, $\mathrm{X}_{j}$-are the independent variables (predictors-Table 1), with $\mathrm{j}=1,2, \ldots, \mathrm{m}, \beta_{\mathrm{j}}$-are the corresponding logit coefficients, and $\varepsilon$ is the error. 
Two forms of the Lasso variable selection procedure (both the cross-validation and the rigorous one) available in Stata 14.2 were involved. This tool was also used for the entire statistical analysis, including post-estimations.

To improve both regional statistical models, we have preserved only variables with a Variance Inflation Factor (VIF) lower than 3.75, while a worrying collinearity is usually considered for values higher than 10 [73]. Then, we kept only the variables with statistical significance ( $\mathrm{p}$ values lower than 0.1) and included them across at least two consecutive scenarios (robustness checks). The resulting scenarios contain different sets of specifications, according to the familial/background and individual characteristics considered in this study ( $\mathrm{a}$ - only the core variable, $\mathrm{b}$ - the core plus only the family/background characteristics, c - the core plus only the individual characteristics, and d-the core plus both types of characteristics).

Lastly, two Zlotnik risk-prediction nomograms were used to assess the probability $[74,75]$ associated with the migration intentions in both particular models, corresponding to respondents' permanent residencies from RoMold and ReMold. These two also contribute to increasing the support for information metrics and decision-making in terms of defining sustainable development policies for the preservation of the young graduates.

Due to our collected data being cross-sectional, there were no causal interpretations between variables in this article, but we have underlined their association in terms of our intentions, which we found in previous research [76,77].

\section{Results and Discussion}

From the very beginning, those two regions (Table 2) reveal noticeable differences in terms of: migration intention (higher frequency of affirmative responses for ReMold), equivalence between our own value recognition and migration (higher frequency of positive responses also for ReMold), interpersonal trust level (slightly stronger for RoMold), parents' migration experience (higher frequency of affirmative responses for ReMold), number of siblings (slightly more numerous for RoMold), and parent's highest level of education attainment (slightly stronger for ReMold).

The results of using online georeferencing tools are available as an online query-able map [72] of coordinates with pushpins (Figure 1). The "Rows 1" button in Figure 1 provides access to the source data and basic support for the replication of results. For reasons related to more persistency in time, we also captured this entire functionality as a short demo [78]. In terms of visual insight, these results show the raw or the filtered distribution of responses considering one or more criteria in the cascade (e.g., the outcome variable and another one corresponding to those four university centers the respondents belong to) with a permanent reference to the number of responses (e.g., 769-Figure 1) meeting the current conditions.

Our previous research and the current results [79] including probabilities returned by SQL DMX queries obtained after applying different DM algorithms (trained with $75 \%$ and $100 \%$ of the data) in SSAS, on both the overall dataset and those two subsets, led us to the idea of a single and most powerful variable acting as the core (strongest predictor) of both regional models. This is the one related to own value recognition (Figure 2) and we explain its overwhelming effect by considering its holistic nature. Influences associated with other variables have also been identified, but they explain the asymmetric patterns of migration intentions, even though these two historical regions have a common language, past, traditions, and history, with ReMold being once part of Romania's territory. This was true until 1940 when it became a republic of the Soviet Union. 
Table 2. General statistics.

\begin{tabular}{|c|c|c|c|c|c|c|c|c|c|c|c|c|c|c|}
\hline Variable & $\begin{array}{c}\text { No. obs. } \\
\text { Ro } \\
\text { Mold }\end{array}$ & Median & Mean & $\begin{array}{l}\text { Standard } \\
\text { Deviation }\end{array}$ & Min & $\operatorname{Max}$ & $\begin{array}{l}\text { Yes (1) } \\
\text { Share }\end{array}$ & $\begin{array}{c}\text { No. obs. } \\
\text { Re } \\
\text { Mold }\end{array}$ & Median & Mean & $\begin{array}{l}\text { Standard } \\
\text { Deviation }\end{array}$ & Min & $\operatorname{Max}$ & $\begin{array}{l}\text { Yes (1) } \\
\text { Share }\end{array}$ \\
\hline inh_val_last_consci_work & 1637 & & & & & & 0.61 & 1070 & & & & & & 0.66 \\
\hline inh_val_indep & 1637 & & & & & & 0.51 & 1070 & & & & & & 0.59 \\
\hline inh_val_sense_of_resp & 1637 & & & & & & 0.82 & 1070 & & & & & & 0.83 \\
\hline inh_val_persev & 1637 & & & & & & 0.61 & 1070 & & & & & & 0.50 \\
\hline inh_val_resp4tradit & 1637 & & & & & & 0.39 & 1070 & & & & & & 0.55 \\
\hline m_edu & 1636 & 12 & 12.39 & 2.60 & 8 & 22 & & 1069 & 12 & 13.13 & 3.63 & 8 & 22 & \\
\hline d_edu & 1633 & 12 & 12.19 & 2.50 & 8 & 22 & & 1062 & 12 & 12.88 & 3.60 & 8 & 22 & \\
\hline no_of_sibl & 1637 & 1 & 1.35 & 1.42 & 0 & 9 & & 1070 & 1 & 1.25 & 1.10 & 0 & 9 & \\
\hline income_lvl & 1637 & 3 & 3.01 & 1.72 & 1 & 7 & & 1067 & 3 & 2.79 & 1.32 & 1 & 7 & \\
\hline both_p_priv & 1637 & & & & & & 0.46 & 1070 & & & & & & 0.39 \\
\hline only_mom_priv & 1637 & & & & & & 0.09 & 1070 & & & & & & 0.09 \\
\hline only_dad_priv & 1637 & & & & & & 0.22 & 1070 & & & & & & 0.23 \\
\hline both_p_faith_God & 1637 & & & & & & 0.52 & 1070 & & & & & & 0.47 \\
\hline only_mom_faith_God & 1637 & & & & & & 0.31 & 1070 & & & & & & 0.29 \\
\hline only_dad_faith_God & 1637 & & & & & & 0.03 & 1070 & & & & & & 0.04 \\
\hline both_p_gone_abroad & 1637 & & & & & & 0.12 & 1070 & & & & & & 0.15 \\
\hline only_mom_gone_abroad & 1637 & & & & & & 0.10 & 1070 & & & & & & 0.10 \\
\hline only_dad_gone_abroad & 1637 & & & & & & 0.19 & 1070 & & & & & & 0.22 \\
\hline urban & 1637 & & & & & & 0.56 & 1070 & & & & & & 0.74 \\
\hline male & 1637 & & & & & & 0.27 & 1070 & & & & & & 0.26 \\
\hline age & 1634 & 20 & 20.47 & 2.69 & 18 & 47 & & 1070 & 20 & 20.46 & 2.19 & 17 & 43 & \\
\hline interpers_trust_lvl & 1632 & 2 & 2.45 & 0.87 & 1 & 5 & & 1066 & 2 & 2.42 & 0.88 & 1 & 5 & \\
\hline clear_eq_migrWEur_pers_val_recog & 1637 & & & & & & 0.23 & 1070 & & & & & & 0.37 \\
\hline clear_intent_to_migr (OUTCOME) & 1637 & & & & & & 0.21 & 1070 & & & & & & 0.40 \\
\hline communist_past_migr_cause & 1637 & & & & & & 0.39 & 1070 & & & & & & 0.49 \\
\hline orthodoxy_migr_cause & 1637 & & & & & & 0.08 & 1070 & & & & & & 0.08 \\
\hline lower_wages_migr_cause & 1637 & & & & & & 0.80 & 1070 & & & & & & 0.82 \\
\hline lower_prof_satisf_migr_cause & 1637 & & & & & & 0.37 & 1070 & & & & & & 0.34 \\
\hline excesive_bureaucracy_migr_cause & 1637 & & & & & & 0.35 & 1070 & & & & & & 0.42 \\
\hline bad_luck_migr_cause & 1637 & & & & & & 0.05 & 1070 & & & & & & 0.07 \\
\hline injust_in_soc_migr_cause & 1637 & & & & & & 0.32 & 1070 & & & & & & 0.42 \\
\hline accept_or_doubts_undsrv_st_fiAdv & 1637 & & & & & & 0.09 & 1070 & & & & & & 0.41 \\
\hline only_strong_conn4cl_acc_in & 1637 & & & & & & 0.31 & 1070 & & & & & & 0.32 \\
\hline indiv_lib_clear_cause_of_progr & 1637 & & & & & & 0.71 & 1070 & & & & & & 0.75 \\
\hline
\end{tabular}

Source: Own calculations in Stata 14.2 MultiProcessing (MP). 


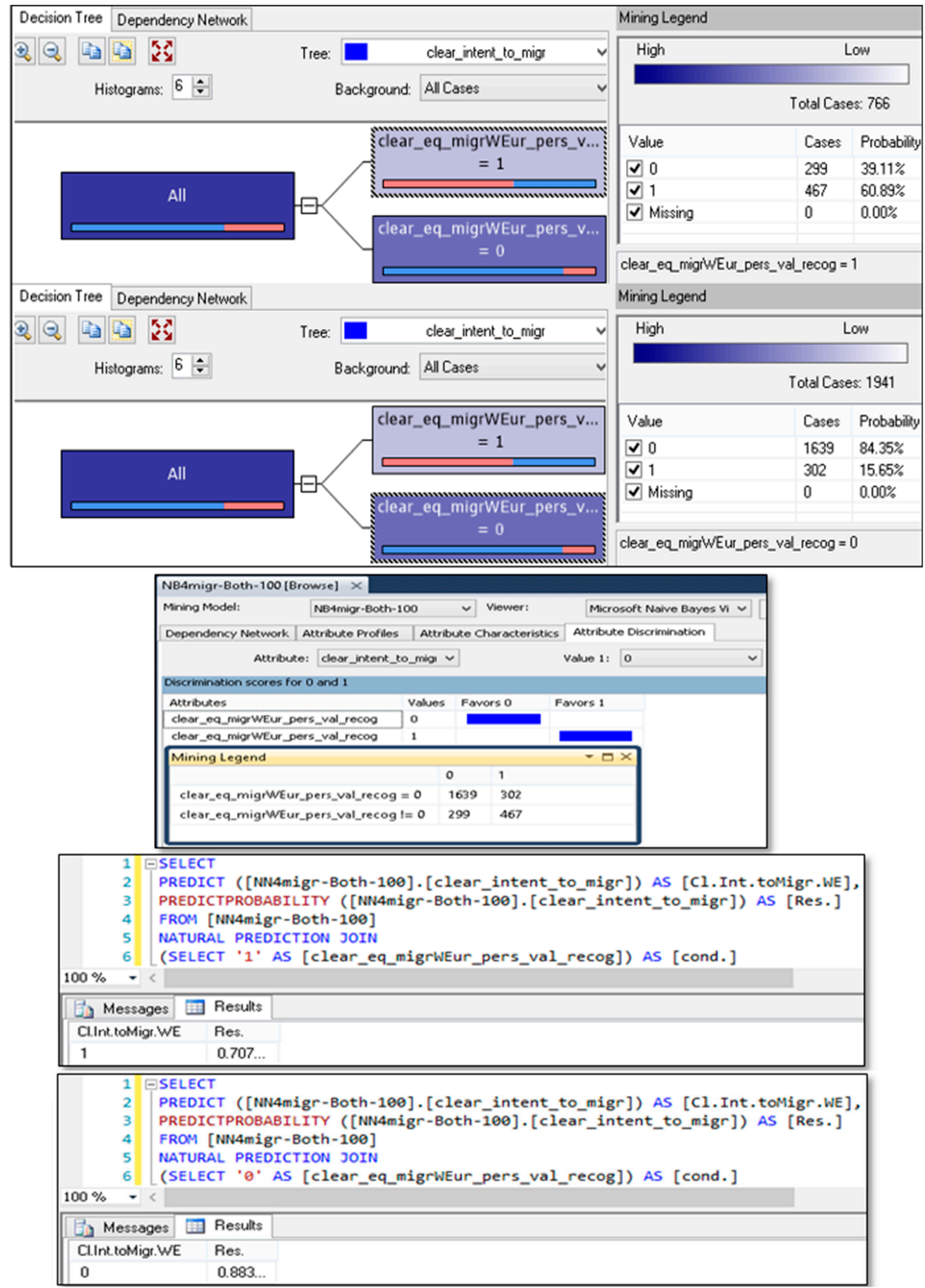

Figure 2. Immediate (design previews) and later results (query-based) after developing DM models using Decision Trees (1st split), Naive Bayes (top 2 rules), and Neural Networks-based classifiers (two SQL DMX queries). 
The results of applying binary logistic regressions on both subsets are available in Tables 3 and 4 and they highly indicate that the patterns of migration intentions have tinted specificities, which demonstrate their asymmetry. Scenario (a) from Table 3 examines the influence of own value recognition on migration intentions. This finding brings additional understanding of the migration potential in non-pecuniary terms. We discovered that own value recognition is the most powerful trigger and this is in line with previous findings in terms of general welfare and career advancement opportunities [30], better standards of living and professional reasons [34,35], life satisfaction [67], subjective well-being [57], and individual self-efficacious behavior [64].

Table 3. Raw coefficients of the model based on responses of students from RoMold.

\begin{tabular}{|c|c|c|c|c|}
\hline \multirow[b]{2}{*}{ Variables } & \multicolumn{4}{|c|}{ Scenarios } \\
\hline & (a) & (b) & (c) & (d) \\
\hline clear_eq_migrWEur_pers_val_recog & $\begin{array}{c}2.327^{* * * *} \\
(0.138)\end{array}$ & $\begin{array}{c}2.328^{* * *} \\
(0.140)\end{array}$ & $\begin{array}{c}2.293^{* * *} \\
(0.141)\end{array}$ & $\begin{array}{c}2.295^{* * *} \\
(0.143)\end{array}$ \\
\hline inh_val_resp4tradit & & $\begin{array}{c}-0.439 * * * \\
(0.146)\end{array}$ & & $\begin{array}{c}-0.404^{* * *} \\
(0.148)\end{array}$ \\
\hline only_dad_priv & & $\begin{array}{c}0.342 \text { ** } \\
(0.164)\end{array}$ & & $\begin{array}{c}0.376^{* *} \\
(0.166)\end{array}$ \\
\hline only_mom_faith_God & & $\begin{array}{c}0.320^{* *} \\
(0.145)\end{array}$ & & $\begin{array}{l}0.334^{* *} \\
(0.147)\end{array}$ \\
\hline interpers_trust_lvl & & & $\begin{array}{c}-0.151 * \\
(0.080)\end{array}$ & $\begin{array}{c}-0.135 \text { * } \\
(0.080)\end{array}$ \\
\hline orthodoxy_migr_cause & & & $\begin{array}{c}0.749 * * * \\
(0.221)\end{array}$ & $\begin{array}{c}0.737^{* * * *} \\
(0.223)\end{array}$ \\
\hline only_strong_conn4cl_acc_in & & & $\begin{array}{l}0.264^{*} \\
(0.145)\end{array}$ & $\begin{array}{c}0.300^{* *} \\
(0.146)\end{array}$ \\
\hline indiv_lib_clear_cause_of_progr & & & $\begin{array}{c}0.382 * * \\
(0.160)\end{array}$ & $\begin{array}{c}0.391 \text { ** } \\
(0.162)\end{array}$ \\
\hline constant & $\begin{array}{c}-2.110 * * * \\
(0.091)\end{array}$ & $\begin{array}{c}-2.136 \text { *** } \\
(0.124)\end{array}$ & $\begin{array}{c}-2.175^{* * *} \\
(0.250)\end{array}$ & $\begin{array}{c}-2.284^{* * *} \\
(0.268)\end{array}$ \\
\hline Number of observations & 1637 & 1637 & 1632 & 1632 \\
\hline VIF (maximum value) & 1 & 1.24 & 2.94 & 3.7 \\
\hline Pseudo R-square & 0.1795 & 0.1902 & 0.1946 & 0.2049 \\
\hline AUC-ROC test (value) & 0.736 & 0.7758 & 0.7794 & 0.7951 \\
\hline
\end{tabular}

Scenario (b) in Table 3 adds certain familial background variables with the potential to explain the migration intention. In our case, only_dad_priv and only_mon_faith_God exert positive influences, by emphasizing an interesting fact, which is that Romanian students who have religious mothers and fathers employed in the private sector are more likely to choose to leave their country of origin. The reason for such a potential decision could be that the paternal and maternal role models matter the most in comparison with other familial features. Moreover, as expected, a negative influence is given by inh_val_resp4tradit, which suggests that the individuals who inherit respect for traditions and historical past from their family are more likely to stay in the country of origin instead of migrate abroad. This is confirmed by previous findings in terms of family ties [47]. 
Table 4. Raw coefficients of the model based on responses of students from ReMold.

\begin{tabular}{|c|c|c|c|c|}
\hline \multirow{2}{*}{ Variables } & \multicolumn{4}{|c|}{ Scenarios } \\
\hline & (a) & (b) & (c) & (d) \\
\hline clear_eq_migrWEur_pers_val_recog & $\begin{array}{c}1.797^{* * * *} \\
(0.139)\end{array}$ & $\begin{array}{c}1.791 \text { *** } \\
(0.140)\end{array}$ & $\begin{array}{c}1.811^{* * * *} \\
(0.140)\end{array}$ & $\begin{array}{c}1.805^{* * *} \\
(0.141)\end{array}$ \\
\hline d_edu & & $\begin{array}{c}-0.0446^{* *} \\
(0.020)\end{array}$ & & $\begin{array}{c}-0.0448^{* *} \\
(0.020)\end{array}$ \\
\hline both_p_gone_abroad & & $\begin{array}{c}0.405^{* *} \\
(0.191)\end{array}$ & & $\begin{array}{c}0.421^{* *} \\
(0.191)\end{array}$ \\
\hline bad_luck_migr_cause & & & $\begin{array}{c}-0.581 \text { ** } \\
(0.278)\end{array}$ & $\begin{array}{c}-0.612 \text { ** } \\
(0.281)\end{array}$ \\
\hline constant & $\begin{array}{c}-1.127^{* * *} \\
(0.090)\end{array}$ & $\begin{array}{c}-0.618^{* *} \\
(0.267)\end{array}$ & $\begin{array}{c}-1.092^{* * *} \\
(0.091)\end{array}$ & $\begin{array}{c}-0.581^{* *} \\
(0.269)\end{array}$ \\
\hline Number of observations & 1070 & 1062 & 1070 & 1062 \\
\hline VIF (maximum value) & 1 & 1.61 & 1.03 & 1.66 \\
\hline Pseudo R-squared & 0.1267 & 0.1341 & 0.1299 & 0.1376 \\
\hline AUC-ROC test (value) & 0.7026 & 0.7306 & 0.7096 & 0.7341 \\
\hline
\end{tabular}

In scenario (c), the influences of the individual features (attitudes and preferences) are brought into analysis. If the Romanian students consider that: Orthodoxy could block the private initiative and, hence, representing a cause of migration, individual liberty is a clear cause for progress and the creed that, only through strong connections somebody could accomplish his career, then they are more likely to prefer to leave abroad. The reverse influence is exerted by interpers_trust_lvl. Those who trust other people the most are more likely to prefer staying in Romania.

The most comprehensive scenario (d) maintains all previous influences (scenarios from a to c). In this direction, the most significant positive influences on the students' willingness to migrate are their own value recognition through the decision to migrate, with the subjective opinion that Orthodoxy could block the individual initiative. Therefore, representing a cause of migration (orthodoxy_migr_cause), the fathers' occupations in the private sector (only_dad_priv), their mothers' high religiosity (only_mon_faith_God), the conviction that individual liberty is a clear cause of progress (indiv_lib_clear_cause_of_progr), and the consideration that, in society, it is necessary to benefit from favoritism and powerful connections in order to have a successful career (only_strong_conn4cl_acc_in). The idea about the blocking role of Orthodoxy on private initiatives should be seen with caution and reserve, since its role in explaining the economic backwardness of Romania in history cannot be attributed to it, but to specific exogenous factors [80]. The last factor is in line with other previous findings [60] in terms of perceived discrimination. Additionally, this is a clue for immoral interactions with a corrupt state and bureaucracy supporting no competition and a lack of meritocracy to take a particular job. This is also a lack of personal morality. As expected, this finding is in line with other previous studies, proving the satisfaction due to the services provided by the public institutions as an inhibitor of migrating abroad [42].

The Pearson goodness-of-fit tests (Prob > chi2) for scenarios (b), (c), and (d) in Table 3 return reasonable values (between 0.27 and 0.44 ), which indicates that this specific model fits well.

Scenario (a) in Table 4 emphasizes the core of the model as being the most significant and powerful variable along all scenarios. It is the variable about own value recognition through migration. Scenario (b) contains familial background variables with the one about both parents' previous migration experience abroad for more than one year (both_p_gone_abroad) and father's highest level of education attainment (d_edu). The first one exerts a positive influence on the dependent variable. Hence, the students who had their parents left for work abroad are more tempted to choose to migrate. Again, 
the intergenerational transmission of parental preferences and behaviors is important and adds more insight into migration intentions' triggers.

The second influence is negative and brings additional power to explain this specific model, emphasizing that the lower the paternal level of educational attainment, the more likely are the respondents to prefer to migrate to Western European countries. Both are in line with previous findings in terms of family networks [46] and family expectations [48].

Scenario (c) brings one individual potential influence. The negative one is generated by bad_luck_migr_cause, which is a variable that highlights the students' opinion that the economic backwardness of the Republic of Moldova in comparison with Western European countries where they intend to migrate is due to bad luck. We could explain this as follows. Those who are not superstitious are more likely to migrate abroad, while not being willing to accept the fatalism about poor economic and institutional status-quo in the Republic of Moldova, considering they are able to change the situation since it is not predetermined by destiny or fate (internal locus of control). This finding confirms previous studies [81], which emphasized that the internal locus of control has an important role in migration decisions. The overall scenario (d) maintains all previous influences (scenarios from a to c).

The Pearson goodness-of-fit tests for scenarios (b), (c), and (d) in Table 4 return better values (between 0.31 and 0.73 ), which indicates that this regional model fits well.

After dragging the perpendiculars and summing up the nomogram scores (from bottom to top) for the identified influences for the most critical combination (Figure 3), we get a total score (24) corresponding to the highest migration intentions' risk (approximately $90 \%$ ), based on a good classifier (ROC $\simeq 0.8$ in Table 3, scenario (d)).

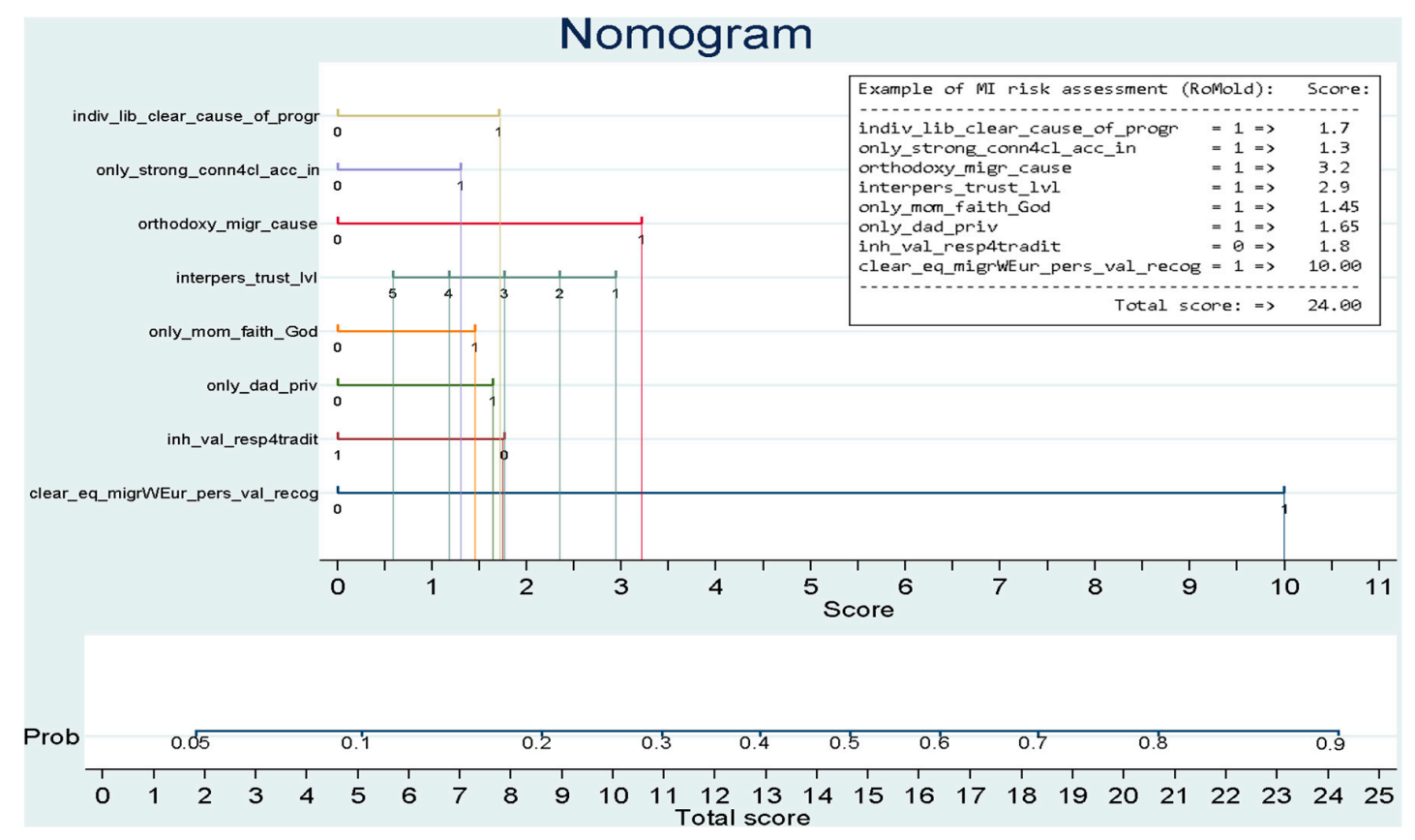

Figure 3. Nomogram for assessing the migration intentions' risk of students in economics from the Moldova region of Romania (RoMold).

In a similar way, the maximum migration intentions' risk (Figure $4-$ more than $80 \%$ for a total score of 21.1, as the sum of 10,5.4, 2.3, and 3.4) is obtained for the second regional model, based on a fair classifier (a ROC value about 0.73 in Table 4 , scenario d). 


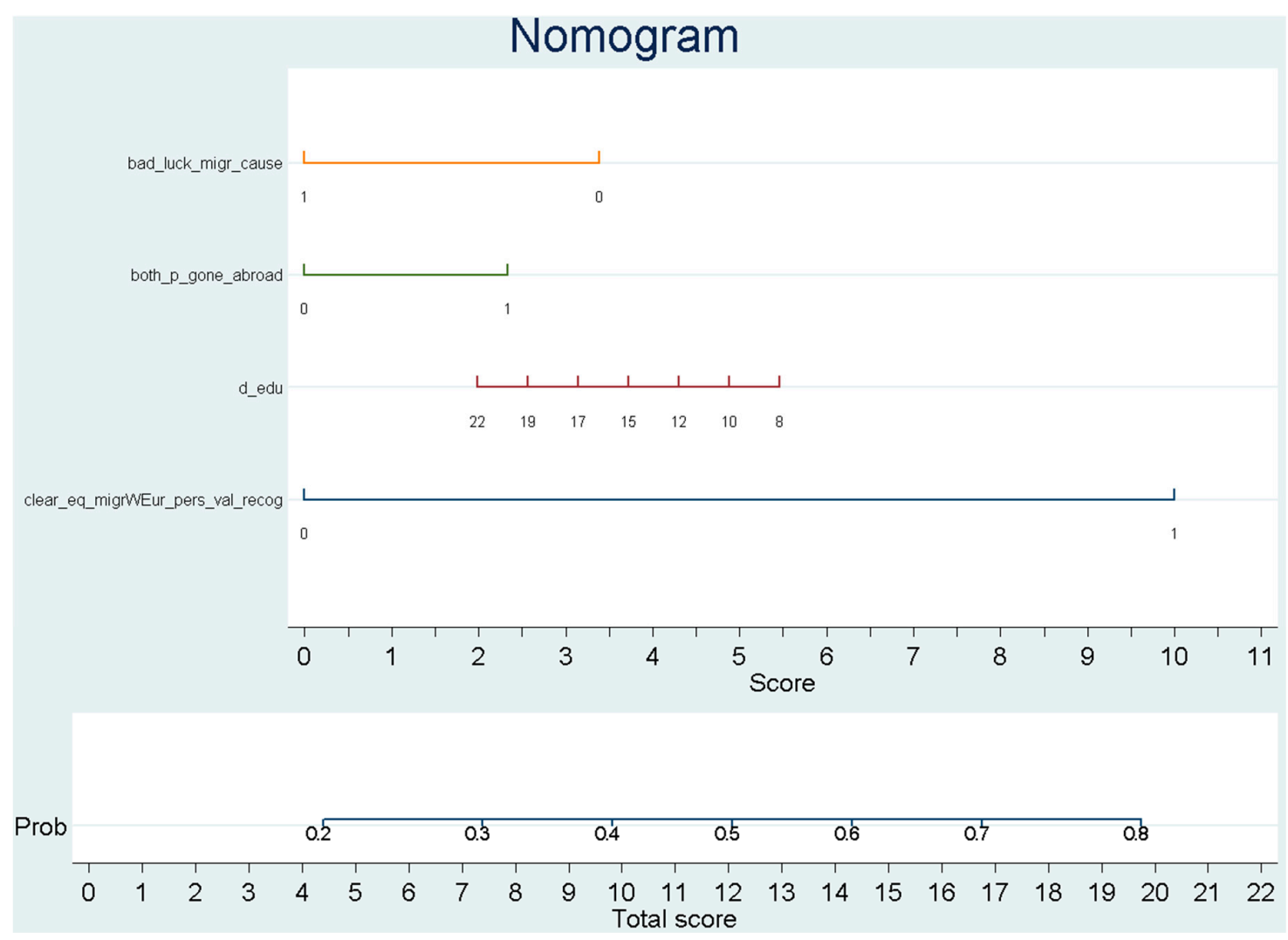

Figure 4. Nomogram for assessing the migration intentions' risk of students in economics from the Republic of Moldova (ReMold).

For other combinations of values for the corresponding predictors identified as the most important ones (Figures 3 and 4), we get lower totals indicating less critical cases in terms of migration intentions' risk.

In terms of validation of the considered hypotheses, Hypothesis 1 is fully validated, Hypothesis 2 is partially and differently confirmed by both specific models, and Hypothesis 3 is partially confirmed (attitude toward individual liberty) and only by the first regional model (RoMold) corresponding to the Romanian region of Moldova. The fourth hypothesis (Hypothesis 4) assesses that the Romanian students who manifest a negative influence toward favoritism in society are more likely to intend to migrate abroad, which, therefore, penalizes the poor quality and inefficient functioning of institutions. The last hypothesis (Hypothesis 5) is invalidated (symmetry breaking), except for the common core of both regional models. Consequently, all other observed influences are different. Therefore, the patterns of migration intentions are asymmetric between these two historical areas.

In terms of limitations of the study, first, we have to admit the difference between some categories of workers. It is worth mentioning the contribution of Massey et al. (1993) [82] who stated that migration intentions are different between skilled and unskilled workers. Consequently, if considering students as a category very close to that of skilled workers, we take into consideration a future study dedicated to analyzing the other distinct category of young people. Moreover, based on the results from this study and on our previous findings, we assume that the core of our existing regional models would still be strong, especially in the case of the same type of respondents from Central and Eastern European countries. We admit that there may be some new influences that could be specific to a particular area. Therefore, we intend to extend this study by analyzing the responses of different types of individuals from other countries, confirm the common part, and identify the peculiarities. 


\section{Conclusions}

The present study explores the factors concerning the students' in economics migration intentions and partially validates a set of hypotheses related to certain familial, background, and individual characteristics that may influence them to leave their countries of origin. The results suggested that the migration intentions could be easily considered as a proxy for low personal value environments or lack meritocracy within society. For both subgroups of students, the lack of meritocratic environments, and, therefore, the difficulty to receive own value recognition within it, is the most powerful trigger that influences the migration intentions. From our findings, this is the only common, but the most powerful, explanatory variable of migration intentions. These results clearly indicate that the Romanian students, in comparison with the Moldavian ones, are less likely to prefer to migrate solely when own value recognition is taken into consideration, which denotes a higher desire for the second group to receive recognition of the personal value they believe they deserve. All other variables are specific for each historical region and underline symmetry breaking patterns of migration intentions' influences. However, these territories were once a Romanian one with a common language, traditions, culture, and past.

For the Romanian region of Moldova, the analysis of the main drivers of the students' migration intentions confirms that the parental role models really matter (if fathers have an occupation in the private sector or if mothers are highly religious) for augmenting the child's migration intentions. These influences, whether quite new in this kind of research, emphasize that the parental role models are important for child's potential decision to migrate abroad, as reflected in other scientific studies $[53,54]$. The ones who subjectively consider that, Orthodoxy could block the individual initiative, and therefore, stimulate the migration abroad, formulate an ideology that is unable to demonstrate its negative influence toward the economic status-quo in certain historical moments. The consideration that, only through favoritism one could obtain a better job, is another positive driver of migration intentions that betray a powerful sensitivity toward interaction with local institutions. Individual liberty, seen as a clear cause of progress, is another positive influence, emphasizing a clear predilection of these students who are willing to leave their country of origin for their own in order to pursue and fulfill their personal goals. Moreover, the ones who put a low emphasis on traditions and historical past are more tempted to leave the country of origin, which indicates a poor sense of belonging to certain cultural, identity, and historical values [83]. Quite strikingly, the lower the level of interpersonal trust, the more the predilection to leave the country of origin, which is a result that emphasizes a perception of inefficient and corrupt public institutions and is in line with other previous studies [84].

In the case of the Republic of Moldova, the students in economics who benefited from previous parental migration experiences abroad are more likely to choose to migrate to other Western European countries. A low level of paternal education attainment is predicted to be another positive influence on the students' propensity to leave their country of origin, which is in contrast with previous findings [85] that stated that such graduates returned to their rural homes in the case of internal migration to Switzerland. Moreover, we found that those students who are not superstitious, hence, putting a great accent on the internal locus of control, are more likely to prefer to make plans to migrate abroad.

In the current context of a Europe marked by a strong demographic decline [70], the risk-prediction nomograms generated for this study, which correspond to the most comprehensive scenarios for both regional models, are nothing other than visual instruments with powerful metrics to support well-orchestrated and sustainable actions adapted to local conditions, meant to stimulate this young component of human capital.

When setting up any policy to intervene against the "brain drain" phenomenon, we must consider that any statistics and results found are hard to be decrypt and translate into proper formulations of policy proposals not just for general conditions, but also for particular ones.

Despite the clear need to separate the policy recommendation part with respect for both the public sector and the private one, every decision maker regardless of the above classification must not forget 
to continuously put a special emphasis on stimulating the own value recognition of individuals, social justice, and transparency, while diminishing the perverted effects of favoritism and corruption.

The state institutions need to be strengthened in order to ensure the fundamental support for law enforcement, promotion of meritocracy and inner sense of national identity, investment in infrastructure for health and public services, and general rules for manifestation of competition and private initiative.

A stronger accent put on the free market is also demanded in order to create support for better business and job opportunities, and actively fight against nepotism and corruption.

The private sector should consider acting responsibly and with respect for productivity, and growth. Moreover, the desire to offer more attractive jobs for highly skilled employees and offer working conditions at high standards should correlate with better investment in capital, and research and development in order to avoid the "brain drain" phenomenon.

Beyond the strong influence of personal value recognition, for any punctual recommendations corresponding to other specific areas, we will need to perform additional tests depending on the occupational profile of the respondents and the level of economic development of the targeted geographic area.

Author Contributions: Conceptualization, A.-P.P., D.H., N.F., O.-A.G., and D.A. Data curation, A.-P.P., D.H., N.F., and O.-A.G. Formal analysis, D.H. and D.A. Investigation, A.-P.P. and D.H. Methodology, A.-P.P. and D.H. Project administration, A.-P.P. Resources, A.-P.P., N.F., and O.-A.G. Software, A.-P.P., D.H., and D.A. Supervision, A.-P.P. and D.A. Validation, A.-P.P., D.H., N.F., O.-A.G., and D.A. Visualization, D.H. and D.A. Writing-original draft, A.-P.P. and D.H. Writing - review \& editing, A.-P.P., D.H., N.F., O.-A.G., and D.A.

Funding: This research received no external funding.

Acknowledgments: We thank all the students who participated in this study and all the staff on the faculties who helped distribute and collect the questionnaires.

Conflicts of Interest: The authors declare no conflict of interest.

\section{References}

1. Iredale, R.R.; Voigt-Graf, C.; Khoo, S.E. Trends in international and internal teacher mobility in three Pacific island countries. Int. Migr. 2012, 53, 97-114. [CrossRef]

2. De Haas, H.; Plug, R. Cherishing the goose with the golden eggs: Trends in migrant remittances from Europe to Morocco 1970-2004. Int. Migr. Rev. 2006, 40, 603-634. [CrossRef]

3. Page, J.; Plaza, S. Migration, Remittances and development: A review of the global evidence. J Afr. Econ. 2006, 15, 245-336. [CrossRef]

4. Favell, A. The new face of East-West migration in Europe. J. Ethn. Migr. Stud. 2008, 34, 701-716. [CrossRef]

5. King, R. Theorising new European youth mobilities. Popul. Space Place 2018, 24, e2117. [CrossRef]

6. McGill, J. The migration of international graduates: Intentions, outcomes, and implications. J. Stud. Int. Educ. 2018, 22, 334-352. [CrossRef]

7. Stemmer, A. The Republic of Moldova and the Migration. Migration and Its Risks and Opportunities for the European Union. Kas International Reports 9/10|2011. Available online: https://www.kas.de/c/document_ library/get_file?uuid=6df80a4c-4967-8f1f-2499-443bf4f8fb87\&groupId=252038 (accessed on 11 July 2019).

8. Goschin, Z. Main Determinants of Romanian Emigration. A Regional Perspective. MPRA Paper No. 88829. 2016. Available online: https://mpra.ub.uni-muenchen.de/88829/1/MPRA_paper_88829.pdf (accessed on 18 July 2018).

9. Waldinger, M.P.F. Studying abroad and the effect on international labour market mobility: Evidence from the introduction of ERASMUS. Econ. J. 2011, 121, 194-222.

10. Sapeha, H. Migrants' intention to move or stay in their initial destination. Int. Migr. 2016, 55, 5-19. [CrossRef]

11. Becerra, D. The impact of anti-immigration policies and perceived discrimination in the United States on migration intentions among Mexican adolescents. Int. Migr. 2012, 50, 20-32. [CrossRef]

12. Creighton, M.J. The role of aspirations in domestic and international migration. Soc. Sci. J. 2013, 50, 79-88. [CrossRef]

13. Van Dalen, H.P.; Henkens, K. Explaining emigration intentions and behaviour in the Netherlands, 2005-2010. Popul. Stud. 2013, 67, 225-241. [CrossRef] [PubMed] 
14. Hoppe, A.; Fujishiro, K. Anticipated job benefits, career aspiration, and generalized self-efficacy as predictors for migration decision-making. Int. J. Intercult. Relat. 2015, 47, 13-27. [CrossRef] [PubMed]

15. Kley, S. Migration in the face of unemployment and unemployment risk: A case study of temporal and regional effects. Comp. Popul. Stud. 2013, 38, 109-136.

16. King, R.; Williams, A.M. Editorial introduction: New European youth mobilities. Popul. Space Place 2018, 24, e2121. [CrossRef]

17. Lu, M. Do people move when they say they will? Inconsistencies in individual migration behavior. Popul. Environ. 1999, 20, 467-488. [CrossRef]

18. Casimiro, S. Return migration: From Australia back to Portugal-the Portuguese experience. Port. Stud. Rev. 2003, 11, 183-203.

19. Zaiceva, A.; Zimmermann, K.F. Scale, diversity, and determinants of labour migration in Europe. Oxf. Rev. Econ. Policy 2008, 24, 427-451. [CrossRef]

20. Kley, S. Facilitators and constraints at each stage of the migration decision process. Popul. Stud. 2017, 71, S35-S49. [CrossRef] [PubMed]

21. Carling, J.; Pettersen, S.V. Return migration intentions in the integration-transnationalism matrix. Int. Migr. 2014, 52, 13-30. [CrossRef]

22. Ajzen, I.; Fishbein, M. Understanding Attitudes and Predicting Social Behavior; Prentice-Hall: Upper Saddle River, NJ, USA, 1980.

23. De Jong, G.F.; Root, B.D.; Gardner, R.W.; Fawcett, J.T.; Abad, R.G. Migration intentions and behavior: Decision making in a rural Philippine province. Popul. Environ. 1985, 8, 41-62. [CrossRef]

24. Bradley, D.; Longino, C.F., Jr.; Stoller, E.P.; Haas, W.H., III. Actuation of mobility intentions among the young-old: An event-history analysis. Gerontologist 2014, 48, 190-202. [CrossRef] [PubMed]

25. Di Belgiojoso, E.B. Intentions on desired length of stay among immigrants in Italy. Genus 2016, 72, 1. [CrossRef]

26. Betts, A.; Collier, P. Refuge: Transforming a Broken Refugee System; Penguin: London, UK, 2017.

27. Tjaden, J.; Auer, D.; Laczko, F. Linking migration intentions with flows: Evidence and potential use. Int. Migr. 2018, 57, 36-57. [CrossRef]

28. Laczko, F.; Tjaden, J.D.; Auer, D. Measuring global migration potential, 2010-2015. Glob. Migr. Data Brief. Ser. 2017, 9, 1-14.

29. IRES-Institutul Român pentru Evaluare și Strategie (Romanian Institute for Evaluation and Strategy). Available online: http://www.ires.com.ro/uploads/articole/research-report-23.01.2013-working-abroad.pdf (accessed on 9 January 2019).

30. YMOBILITY-Youth Mobility. Available online: http://www.ymobility.eu/wp-content/uploads/ SpheresLifeYouthMigProcess1.pdf (accessed on 21 January 2019).

31. Aidis, R.; Krupickaitë, D.; Blinstrubaitë, L. The loss of intellectual potential: Migration tendencies amongst university students in Lithuania. Geografija 2005, 41, 33-40.

32. Venhorst, V.; van Dijk, J.; van Wissen, L. Do the best graduates leave the peripheral areas of the Netherlands? Tijdschr. Econ. Soc. Geogr. 2010, 101, 521-537. [CrossRef]

33. Coniglio, N.D.; Prota, F. Human capital accumulation and migration in a peripheral EU region: The case of Basilicata. Pap. Reg. Sci. 2008, 87, 77-95. [CrossRef]

34. Bijwaard, G.E.; Wang, Q. Return migration of foreign students. Eur. J. Popul. 2016, 32, 31-54. [CrossRef]

35. Mosneaga, A.; Winther, L. Emerging talents? International students before and after their career start in Denmark. Popul. Space Place 2013, 19, 181-195. [CrossRef]

36. Todaro, M.P. A model of labor migration and urban unemployment in less developed countries. Am. Econ. Rev. 1969, 59, 138-148.

37. Kırdar, M.G.; Saracoglu, D.S. Migration and Regional convergence: An empirical investigation for Turkey. Pap. Reg. Sci. 2008, 87, 545-567. [CrossRef]

38. Nikolova, M.; Graham, C. In Transit: The well-being of migrants from transition and post-transition countries. J. Econ. Behav. Org. 2015, 112, 164-186. [CrossRef]

39. Esipova, N.; Ray, J.; Pugliese, A. Gallup World Poll: The Many Faces of Global Migration; International Organization for Migration: Geneva, Switzerland, 2011; pp. 1-71. Available online: http://publications.iom. int/system/files/pdf/mrs43.pdf (accessed on 3 September 2018). 
40. Migali, S.; Scipioni, M. A Global Analysis of Intentions to Migrate. European Commission 2018, JRC111207. Available online: https://ec.europa.eu/jrc/sites/jrcsh/files/technical_report_on_gallup_v7_finalpubsy.pdf (accessed on 15 January 2019).

41. Dao, T.H.; Docquier, F.; Parsons, C.; Peri, G. Migration and development: Dissecting the anatomy of the mobility transition. J. Dev. Econ. 2018, 132, 88-101. [CrossRef]

42. Dustmann, C.; Okatenko, A. Out-migration, wealth constraints, and the quality of local amenities. Land Prop. Rights 2014, 110, 52-63. [CrossRef]

43. Fouarge, D.; Ester, P. How Willing Are Europeans to Migrate? A Comparison of Migration Intentions in Western and Eastern Europe. In Innovating European Labour Markets, Dynamics and Perspectives; Ester, P., Muffels, R., Schippers, J., Wilthagen, T., Eds.; Edward Elgar Publishing Limited: Cheltenham, UK, 2008; pp. $49-71$.

44. Docquier, F.; Giovanni, P.; Ruyssen, I. The cross-country determinants of potential and actual migration. Int. Migr. Rev. 2014, 48, S37-S99. [CrossRef]

45. Ruyssen, I.; Salomone, S. Female migration: A way out of discrimination? J. Dev. Econ. 2018, 130, $224-241$. [CrossRef]

46. Heering, L.; van der Erf, R.; van Wissen, L. The role of family networks and migration culture in the continuation of Moroccan emigration: A gender perspective. J. Ethn. Migr. Stud. 2004, 30, 323-337. [CrossRef]

47. Munshi, K.; Rosenzweig, M. Why Is Mobility in India so Low? Social Insurance, Inequality, and Growth. NBER Working Paper No.14850. 2009. Available online: https://www.nber.org/papers/w14850.pdf (accessed on 3 June 2018).

48. Nauck, B.; Settle, B. Immigrant and ethnic minority families: An introduction. J. Comp. Fam. Stud. 2001, 32, 461-463.

49. Frieze, I.H.; Boneva, B.S.; Šarlija, N.; Horvat, J.; Ferligoj, A.; Kogovšek, T.; Miluska, J.; Popova, L.; Korobanova, J.; Sukhareva, N.; et al. Psychological differences in stayers and leavers: Emigration desires in Central and Eastern European university students. Eur. Psychol. 2004, 9, 15-23. [CrossRef]

50. Waite, L.; Lehrer, E. The benefits from marriage and religion in the United States: A comparative analysis. Popul. Dev. Rev. 2003, 29, 255-275. [CrossRef]

51. Gungor, D.; Fleischmann, F.; Phalet, K. Religious identification, beliefs, and practices among Turkish Belgian and Moroccan Belgian Muslims: Intergenerational continuity and acculturative change. J. Cross Cult. Psychol. 2011, 42, 1356-1374. [CrossRef]

52. Wiese, B.S.; Freund, A.M. Parents as role models: Parental behavior affects adolescents' plans for work involvement. Int. J. Behav. Dev. 2011, 35, 218-224. [CrossRef]

53. Thissen, F.; Fortuijn, J.D.; Strijker, D.; Haartsen, T. Migration intentions of rural youth in the Westhoek, Flanders, Belgium and the Veenkoloniën, The Netherlands. J. Rural Stud. 2010, 26, 428-436. [CrossRef]

54. Bjarnason, T.; Thorlindsson, T. Should I stay or should I go? Migration expectations among youth in Iceland fishing and farming communities. J. Rural Stud. 2006, 22, 290-300. [CrossRef]

55. Rye, J.F. Youth migration, rurality and class: A Bourdieusian approach. Eur. Urban Reg. Stud. 2011, 18, 170-183. [CrossRef]

56. Corbett, M. Rural education and out-migration: The case of a coastal community. Can. J. Educ. 2005, 28, 52-72. [CrossRef]

57. Cai, R.; Esipova, N.; Oppenheimer, M.; Feng, S. International migration desires related to subjective well-being. IZA J. Migr. 2014, 3, 8. [CrossRef]

58. Vlase, I. 'My husband is a patriot!': Gender and Romanian family return migration from Italy. J. Ethn. Migr. Stud. 2013, 39, 741-758. [CrossRef]

59. Erdal, M.B.; Ezzati, R. 'Where are you from' or 'when did you come?' Temporal dimensions in migrants' reflections about settlement and return. Ethn. Racial Stud. 2014, 38, 1202-1217. [CrossRef]

60. Groenewold, G.; de Valk, H.A.G. Acculturation style, transnational behaviour, and return-migration intentions of the Turkish second generation: Exploring linkages. Demogr. Res. 2017, 37, 1707-1734. [CrossRef]

61. Almlund, M.; Duckworth, A.L.; Heckman, J.; Kautz, T. Personality psychology and economics. In Handbook of the Economics of Education; Hanushek, E.A., Machin, S., Woessmann, L., Eds.; Elsevier: Waltham, MA, USA, 2011; Volume 4, pp. 1-181. 
62. Borghans, L.; Duckworth, A.L.; Heckman, J.J.; Weel, B.T. The economics and psychology of personality traits. J. Hum. Res. 2008, 43, 972-1059. [CrossRef]

63. Caliendo, M.; Cobb-Clark, D.A.; Hennecke, J.; Uhlendorff, A. Job Search, Locus of Control, and Internal Migration; IZA Discussion Paper No. 9600; IZA: Bonn, Germany, 2016.

64. Groenewold, G.; de Bruijn, B.; Bilsborrow, R. Psychosocial factors of migration: Adaptation and application of the health belief model. Int. Migr. 2012, 50, 211-231. [CrossRef]

65. Bauernschuster, S.; Falck, O.; Heblich, S.; Suedekum, J.; Lameli, A. Why are educated and risk-loving persons more mobile across regions? J. Econ. Behav. Org. 2014, 98, 56-69. [CrossRef]

66. De Jong, G.F. Expectations, gender, and norms in migration decision-making. Popul. Stud. 2000, 54, 307-319. [CrossRef] [PubMed]

67. Chindarkar, N. Is subjective well-being of concern to potential migrants from Latin America? Soc. Indic. Res. 2014, 115, 159-182. [CrossRef]

68. Baláž, V.; Williams, A.; Fifeková, E. Migration decision making as complex choice: Eliciting decision weights under conditions of imperfect and complex information through experimental methods. Popul. Space Place 2014, 22, 36-53. [CrossRef]

69. Plopeanu, A.P.; Homocianu, D.; Necula, C.V. A study on the emigration enablers of the Romanian students in theology. Rev. Românească Educ. Multidimens. 2018, 10, 180-197. [CrossRef]

70. Plopeanu, A.P.; Homocianu, D.; Mihăilă, A.A.; Crișan, E.L.; Bodea, G.; Bratu, R.D.; Airinei, D. Exploring the influence of personal motivations, beliefs and attitudes on students' Post-Graduation Migration Intentions: Evidence from Three Major Romanian Universities. Appl. Sci. 2018, 8, 2121. [CrossRef]

71. Munafò, M.R.; Smith, G.D. Robust research needs many lines of evidence. Nature 2018, 553, $399-401$. [CrossRef] [PubMed]

72. A Symmetric Analysis of Post-Graduation Migration Intention Patterns of Students in Economics from Eastern Europe-Distribution Map. Available online: https://fusiontables.google.com/data?docid= 1SIKDWXDxmx9Z0pyqao4a6rhFNxpN45uJVv4Cto8o\#map:id=3 (accessed on 28 May 2019).

73. Salmerón, R.; García, C.B.; García, J. Variance Inflation Factor and Condition Number in Multiple Linear Regression. J. Stat. Comput. Simul. 2018, 88, 2365-2384. [CrossRef]

74. Zlotnik, A.; Abraira, V. A general-purpose nomogram generator for predictive logistic regression models. Stata J. 2015, 15, 537-546. [CrossRef]

75. Lionte, C.; Sorodoc, V.; Jaba, E.; Botezat, A. Development and validation of a risk-prediction nomogram for in-hospital mortality in adults poisoned with drugs and non-pharmaceutical agents. An observational study. Medicine 2017, 96, e6404. [CrossRef] [PubMed]

76. De Haas, H.; Fokkema, T. The effects of integration and transnational ties on international return migration intentions. Demogr. Res. 2011, 25, 755-782. [CrossRef]

77. De Vroome, T.; Van Tubergen, F. Settlement intentions of recently arrived Immigrants and refugees in the Netherlands. J. Immigr. Refug. Stud. 2014, 12, 47-66. [CrossRef]

78. Short Demo About a Symmetric Analysis of Eastern European Economics Students' Migration Intentions. Available online: https://youtu.be/vWE7CiYhyj4 (accessed on 28 May 2019).

79. Data Mining Support Tests for a Study Regarding the Migration Intentions of Students in Economics from Eastern Europe. Available online: https://sites.google.com/site/supp4replication2xmigr/dwld (accessed on 28 May 2019).

80. Murgescu, B. Romania and Europe. The Accumulation of Development Lags (1500-2010); Polirom: Iasi, Romania, 2010.

81. Kahana, E.; Segall, M.; Vosmik, J.L.; Kahana, B.; Riley, K.P. Motivators, resources and barriers in voluntary international migration of the elderly: The case of Israel-bound aged. J. Cross Cult. Gerontol. 1986, 1, 191-208. [CrossRef]

82. Massey, D.S.; Arango, J.; Hugo, G.; Kouaouci, A.; Pellegrino, A.; Taylor, J.E. Theories of international migration: A review and appraisal. Popul. Dev. Rev. 1993, 19, 431-466. [CrossRef]

83. Grace, P.; Bramston, P.; Patrick, J.; Pannach, W. The relevance of community sentiments to Australian rural youths' intention to stay in their home communities. Am. Behav. Sci. 2006, 50, 226-240. 
84. Letki, N. Social capital in East-Central Europe. In Handbook of Social Capital. The Troika of Sociology, Political Science and Economics; Svendsen, G.T., Svendsen, G.L.H., Eds.; Edward Elgar: Cheltenham, UK, 2009.

85. Rerat, P. The selective migration of young graduates: Which of them return to their rural home region and which do not? J. Rural Stud. 2014, 35, 123-132. [CrossRef]

(C) 2019 by the authors. Licensee MDPI, Basel, Switzerland. This article is an open access article distributed under the terms and conditions of the Creative Commons Attribution (CC BY) license (http://creativecommons.org/licenses/by/4.0/). 